\title{
Modelling of Protective Mechanism of Iron(II)-polyphenol Binding with OH-related Molecular Descriptors
}

\author{
Ante Miličević, ${ }^{*}$ Nenad Raos \\ Institute for Medical Research and Occupational Health, Ksaverska c. 2, P.O. Box 291, HR-10001 Zagreb, Croatia \\ * Corresponding author's e-mail address: antem@imi.hr
}

RECEIVED: September 19, 2016 * REVISED: November 21, 2016 * ACCEPTED: November 21, 2016

THIS PAPER IS DEDICATED TO PROF. NENAD TRINAJSTIĆ ON THE OCCASION OF HIS 80² BIRTHDAY

\begin{abstract}
The linear models for the calculation of $\mathrm{plC}_{50}, \mathrm{p} K_{\mathrm{a} 1}$ and $\mathrm{Ep}_{\mathrm{a}}$ for 12 polyphenolic compounds (catechins, flavonols, catechol and gallol derivatives) were developed. As descriptors we used the number of vicinal $\left(N_{\mathrm{v}}\right)$ and non-vicinal $\left(N_{\mathrm{nv}}\right) \mathrm{OH}$ groups, as well as the number of $\mathrm{OH}$ vicinal pairs as possible $\mathrm{Fe}^{2+}$ chelate sites $\left(N_{\mathrm{ch}}\right)$. The models gave $r>0.9$ and standard errors of $0.13,0.26$ and 0.04 for $\mathrm{plC} \mathrm{C}_{50}, \mathrm{p} K_{\mathrm{a} 1}$ and $E \mathrm{p}_{\mathrm{a}}$, respectively. For modelling of $\mathrm{plC}_{50}, N_{\mathrm{ch}}$ is better variable than $N_{\mathrm{v}}$, and vice versa for modelling of $\mathrm{p} K_{\mathrm{a} 1}$ and $E \mathrm{p}_{\mathrm{a}}$. This result, along with good correlations between $\mathrm{plC}_{50}, \mathrm{p} K_{\mathrm{a} 1}$ and $E \mathrm{p}_{\mathrm{a}}$, suggests two effects for antioxidative activity of polyphenols; their reaction(s) with $\mathrm{OH}$ and prevention of Fenton reaction by $\mathrm{Fe}^{2+}$ chelation.
\end{abstract}

Keywords: antioxidative activity, Fenton reaction, DNA damage, QSAR.

\section{INTRODUCTION}

$\mathbf{T}$ HE protective action of polyphenols is well known, ${ }^{[1-5]}$ but the mode of their action has not yet been sufficiently explained. There are general reaction mechanisms for scavenging of radicals by polyphenols, such as single-step hydrogen atoms transfer (HAT), single electron transfer followed by proton transfer (SET-PT) and sequential proton loss electron transfer (SPLET). ${ }^{[6,7,8]}$ However, this paper is concerned with the mechanism involving polyphenol interaction with iron(II), ${ }^{[9]}$ preventing in this way Fenton reaction: ${ }^{[10,11]}$

$$
\mathrm{Fe}^{2+}+\mathrm{H}_{2} \mathrm{O}_{2} \rightarrow \mathrm{Fe}^{3+}+\mathrm{HO}^{-}+\cdot \mathrm{OH}
$$

The last mechanism is also relevant to DNA damage because hydroxyl radical is the primary cause of cell death under oxidative stress conditions. ${ }^{[12,13]}$ The protective role of polyphenols is thus viewed as being iron(II) chelators, preventing the reduction of $\mathrm{Fe}^{2+}$ with $\mathrm{H}_{2} \mathrm{O}_{2}$. The theory is supported by direct experimental evidence, ${ }^{[14,15]}$ as well as the study of polyphenol binding to iron(II) and other heavy metals. ${ }^{[16-21]}$ Analogous mechanism was also proposed for copper(I)/ copper(II) system, but it proved less efficient than the already mentioned. ${ }^{[22,23]}$

There is yet no general regression model (QSAR or QSPR) for the activity and physicochemical properties of polyphenols, despite many models with various molecular descriptors were tried. The binding of flavonoids to P-glycoprotein was modelled by sophisticated CoMFA and CoMSIA methods ${ }^{[24]}$ and MIFs and VolSurf descriptors, ${ }^{[25]}$ but also using a simple linear model based on zero-order valence molecular connectivity index. ${ }^{[26]}$ The flavonoid toxicity ( $\log \mathrm{CL}_{50}$ ) to $\mathrm{HL}-60$ and lamb embrio kidney fibroblast (FLK) cells were correlated to polarographic oxidation half-peak potential $\left(E_{2 / p}\right)$ and water / octanol partition coefficient $(\log P)$ yielding in two-variable linear regression satisfactory correlation for HL-60 $\left(r^{2}=0.915\right)$, but not for FLK cells $\left(r^{2}=0.674\right)$. ${ }^{[27]}$ Filipović and co-workers correlated VCEAC (antioxidant capacity equivalent to vitamin $C$ concentration) values for 21 polyphenols with a 
number of descriptors, but BDE (bond dissociation enthalpy), PA (proton affinity), ETE (electron-transfer enthalpy) and $\mathrm{nOH}_{\text {vic }}$ (number of vicinal $\mathrm{OH}$ groups) proved best. ${ }^{[28]}$ By combining two $\left(\mathrm{BDE}, \mathrm{nOH}_{\text {vic }}\right)$ and three descriptors (PA, ETE, $\mathrm{nOH}_{\text {vic }}$ ) they obtained $r=0.957$ and $r=0.962$ for the first and the second model, respectively. The similar model was used by Amić et al. on the set of 29 flavonoids $(r=0.974) .{ }^{[29]}$ Perron and coworkers used $p K_{a}$ of the most acidic phenolic hydrogen as a sole descriptor for the modeling of inhibition of DNA damage under Fenton reaction conditions, but found the same regression cannot be successfully used for all the investigated polyphenols. ${ }^{[15]}$ However, $\mathrm{p} K_{\mathrm{a}}$ proved significantly better descriptor than the reduction or oxidation potential.
The aim of this contribution is to apply on the mentioned DNA system ${ }^{[15]}$ a simpler, but possibly more successful set of molecular descriptors. For that purpose we chose descriptors based on number and position of phenolic and other hydroxyl group (alcoholic, carboxylic) in the molecules of polyphenols.

\section{METHODS}

For the given set of 12 polyphenols (catechins, flavonols, catechol and gallol derivatives, Figure 1) we tried to estimate their antioxidative activity by modelling $\mathrm{plC}_{50}$ (obtained from the percentage of DNA damage inhibition) and $E \mathrm{p}_{\mathrm{a}}$ (oxidation potential), as well as $\mathrm{p} K_{\mathrm{a} 1}$ values of the<smiles>O=C(O[C@H]1Cc2c(O)cc(O)cc2O[C@H]1c1cc(O)c(O)c(O)c1)c1cc(O)c(O)c(O)c1</smiles>

(-)-epigallocatechin-3-gallate (EGCG)<smiles>COC(=O)c1cc(O)c(O)c(O)c1</smiles>

methyl 3,4,5-trihydroxybenzoate (MEGA)<smiles>O=c1c(O)c(-c2ccc(O)c(O)c2)oc2cc(O)cc(O)c12</smiles>

quercetin (Q)<smiles>O=C(O)c1ccc(O)c(O)c1</smiles>

protocatechuic acid (PCA)<smiles>O=c1c(O)c(-c2cc(O)c(O)c(O)c2)oc2cc(O)cc(O)c12</smiles>

myricetin (Myr)<smiles>CCCOC(=O)c1cc(O)c(O)c(O)c1</smiles>

n-propyl gallate (PrEGA)<smiles>O=C(O)c1cc(O)c(O)c(O)c1</smiles>

gallic acid (GA)<smiles>Oc1cc(O)c2c(c1)O[C@H](c1ccc(O)c(O)c1)[C@H](O)C2</smiles>

(-)-epicatechin (EC)<smiles>O=C(O[C@H]1Cc2c(O)cc(O)cc2O[C@H]1c1ccc(O)c(O)c1)c1cc(O)c(O)c(O)c1</smiles>

(-)-epicatechin-3-gallate (ECG)<smiles>Oc1cc(O)c2c(c1)O[C@H](c1cc(O)c(O)c(O)c1)[C@H](O)C2</smiles>

(-)-epigallocatechin (EGC)<smiles>COC(=O)c1ccc(O)c(O)c1</smiles>

methyl 3,4-dihydroxybenzoate (MEPCA)<smiles>COc1cc(C(=O)O)ccc1O</smiles>

vanillic acid (VA)

Figure 1. Structures of polyphenolic compounds and their abbreviations. 
most acidic (phenolic) hydrogen compiled from six different sources. ${ }^{[15]}$

The variables used for modelling $\mathrm{plC}_{50}$ of polyphenols are related to the number and position of $\mathrm{OH}$ groups in molecule viz. the number of vicinal $\left(N_{\mathrm{v}}\right)$ and of non-vicinal $\left(N_{\text {nv }}\right) \mathrm{OH}$ groups, and the number of $\mathrm{OH}$ pairs which may form a stable five-membered chelate rings with $\mathrm{Fe}^{2+}\left(N_{\mathrm{ch}}\right)$. As carbonyl oxygen of flavonols participates in $\mathrm{Fe}^{2+}$ chelation, ${ }^{[30]}$ it is treated in the same way as $\mathrm{OH}$ group.

Regression calculations, including the leave-one-out procedure (LOO) of cross validation were done using the CROMRsel program. ${ }^{[31]}$ The standard error of the crossvalidation estimate was defined as:

$$
\text { S.E. }{ }_{\mathrm{cv}}=\sqrt{\sum_{i} \frac{\Delta X_{i}^{2}}{N-1}}
$$

where $\Delta X$ and $N$ denotes $\mathrm{cv}$ residuals and the number of reference points, respectively.

\section{RESULTS AND DISCUSSION}

From Table 2 it can be seen that Model 2 (Figure 2) is consistently better than Model 1 . Variable $N_{\text {ch }}$, if taken alone, is better descriptor $(r=0.946)$ than $N_{\mathrm{v}}(r=0.922)$ when correlated to $\mathrm{plC}_{50}$. This speaks in favour of the assumption ${ }^{[9,15]}$ that $\mathrm{Fe}^{2+}$ chelation is the dominant effect for antioxidative activity, for $N_{\mathrm{ch}}$ is a measure of chelating capacity of the studied compounds.

As shown previously, ${ }^{[15]} \mathrm{plC}_{50}$ shows also a good correlation with $\mathrm{p} K_{\mathrm{a} 1}(r=-0.897$, Figure 3$)$, but our models proved better and they don't use experimental values as descriptors. Correlation of $\mathrm{p} K_{\mathrm{a} 1}$ to $\mathrm{plC}_{50}$ also points to the ability of iron bonding, but $\mathrm{p} K_{\mathrm{a} 1}$ is not directly related to chelate but rather to inductive effect (electron affinity). This suggests that both effects participate in the antioxidative activity of polyphenols. Comparison of
Models 3 and 4 leads to the same conclusion. Model 3 is better than Model 4, and $\mathrm{p} K_{\mathrm{a} 1}$ correlates better with $N_{\mathrm{v}}(r=$ $-0.867)$ than with $N_{\text {ch }}(r=-0.818)$. Namely, $N_{v}$ is not related directly to the number of chelation sites but to the number of neighbouring $\mathrm{OH}$ groups which mutually affect acidity.

We also correlated oxidation potential, $\mathrm{Ep}_{\mathrm{a}}$, to $\mathrm{plC}_{50}$ $(r=-0.770)$ and to $\mathrm{p} K_{\mathrm{a} 1}(r=0.824)$ (Figures 4 and 5), which is comparable with the previously published results of $E p_{a}$ vs. $\mathrm{IC}_{50}$ for six cateholate compound $(r=-0.889)$. ${ }^{[15]}$ The correlations were substantially improved after removal of EGCG (the highest $N_{\mathrm{ch}}$ and the highest $\mathrm{plC}_{50}$ ) and other catechins (ECG, EGC, and EC); we obtained $r=-0.953$ and 0.969 for $E p_{a}, v s$. $p I C_{50}$ and $E p_{a}, v s$. $p K_{\mathrm{a} 1}$, respectively. Also, for the estimation of $E p_{a}$, Model 5 proved better than model 6, and $N_{\mathrm{v}}$ gives higher correlation $(r=-0.933)$ than $N_{\text {ch }}(r=-0.911)$ with $E p_{a}$.

Table 1. $\mathrm{plC}_{50}, \mathrm{p} K_{\mathrm{a} 1}$ and $E \mathrm{p}_{\mathrm{a}}$ values ${ }^{[15]}$ for 12 polyphenolic compounds and number of vicinal, $N_{\mathrm{v}}$, and nonvicinal, $N_{\mathrm{nv}}$, $\mathrm{OH}$ groups and $\mathrm{OH}$ pairs as chelation sites, $N_{\text {ch }}$.

\begin{tabular}{ccccccc}
\hline polyphenol & $\mathrm{pIC}_{50}$ & $\mathrm{p} K_{\mathrm{a} 1}$ & $E \mathrm{p}_{\mathrm{a}} / \mathrm{V}$ & $N_{\mathrm{v}}$ & $N_{\mathrm{nv}}$ & $N_{\mathrm{ch}}$ \\
\hline EGCG & 5.9586 & 7.55 & 0.293 & 6 & 2 & 4 \\
Myr $^{(\mathrm{a})}$ & 5.6990 & 6.89 & 0.169 & 5 & 2 & 3 \\
ECG & 5.6383 & 7.6 & 0.316 & 5 & 2 & 3 \\
MEGA & 5.3979 & 7.90 & 0.293 & 3 & 0 & 2 \\
PrEGA & 5.2924 & 7.77 & 0.288 & 3 & 0 & 2 \\
EGC & 5.0088 & 8.51 & 0.255 & 3 & 3 & 2 \\
Q ${ }^{(a)}$ & 4.9706 & 7.65 & 0.250 & 4 & 2 & 2 \\
GA & 4.8539 & 8.45 & 0.433 & 3 & 1 & 2 \\
MEPCA & 4.8069 & 8.12 & 0.380 & 2 & 0 & 1 \\
PCA & 4.4634 & 8.64 & 0.538 & 2 & 1 & 1 \\
EC & 4.2284 & 8.76 & 0.356 & 2 & 3 & 1 \\
VA & 3.8539 & 9.39 & 0.771 & 0 & 2 & 0 \\
\hline
\end{tabular}

(a) Carbonyl oxygen is treated as $\mathrm{OH}$ group.

Table 2. Linear models for the estimation of $\mathrm{pIC}_{50}, \mathrm{p} K_{\mathrm{a} 1}$ and $E \mathrm{p}_{\mathrm{a}}$.

\begin{tabular}{|c|c|c|c|c|c|c|c|c|c|}
\hline \multirow{2}{*}{$\begin{array}{l}\text { Model } \\
\text { No. }\end{array}$} & \multirow{2}{*}{$N$} & \multirow{2}{*}{$\begin{array}{l}\text { Dependent } \\
\text { variable }\end{array}$} & \multicolumn{3}{|c|}{$\begin{array}{c}\text { Slope (S.E.) } \\
\text { Independent variable }\end{array}$} & \multirow{2}{*}{$\begin{array}{l}\text { Intercept } \\
\text { (S.E.) }\end{array}$} & \multirow{2}{*}{$r$} & \multirow{2}{*}{ S.E. } & \multirow{2}{*}{ S.E.cv } \\
\hline & & & $N_{\text {ch }}$ & $N_{v}$ & $N_{\text {nv }}$ & & & & \\
\hline 1 & 12 & $\mathrm{plC}_{50}$ & - & $0.368(35)$ & $-0.161(53)$ & $4.09(14)$ & 0.963 & 0.16 & 0.21 \\
\hline 2 & 12 & $\mathrm{plC} \mathrm{C}_{50}$ & $0.563(41)$ & - & $-0.141(41)$ & $4.15(10)$ & 0.977 & 0.13 & 0.17 \\
\hline 3 & 12 & $\mathrm{p} K_{\mathrm{a} 1}$ & - & $-0.376(57)$ & $0.180(86)$ & $9.02(22)$ & -0.913 & 0.26 & 0.34 \\
\hline 4 & 12 & $\mathrm{p} K_{\mathrm{a} 1}$ & $-0.53(11)$ & - & $0.15(11)$ & $8.89(27)$ & -0.854 & 0.34 & 0.44 \\
\hline 5 & 8 & $E p_{a}$ & - & $-0.124(13)$ & $0.059(21)$ & $0.672(43)$ & -0.975 & 0.04 & 0.07 \\
\hline 6 & 8 & $E p_{a}$ & $-0.191(34)$ & - & $0.038(34)$ & $0.662(72)$ & -0.930 & 0.07 & 0.10 \\
\hline
\end{tabular}




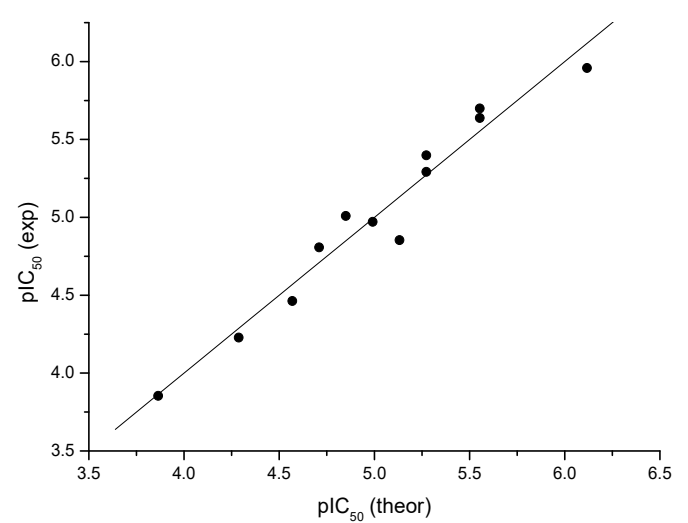

Figure 2. Experimental vs. theoretical $\mathrm{plC}_{50}$ values for 12 polyphenoles (Model 2, Table 2).

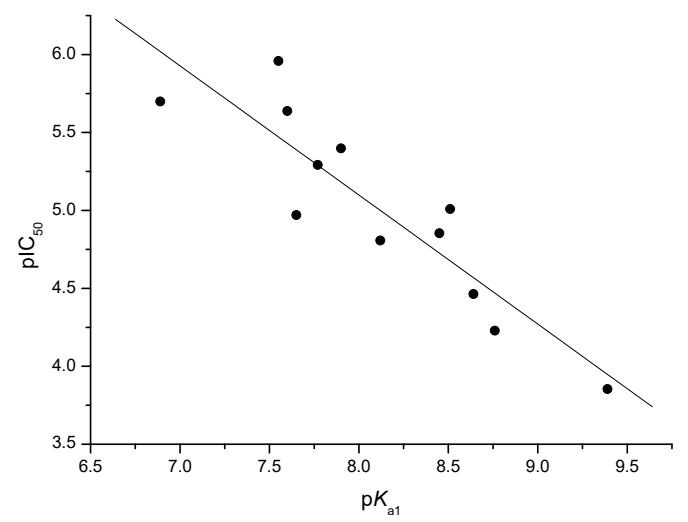

Figure 3. Correlation of experimental $p K_{\mathrm{a} 1}$ to $\mathrm{pIC} \mathrm{C}_{50}$ values for 12 polyphenoles; $r=-0.897$, S.E. $=0.27$, S.E.cv $=0.32$.

As the oxidation potential is a measure of ability for releasing of electrons, it is related to the antioxidative mechanisms involving reaction of polyphenols with $\cdot \mathrm{OH}$. We would therefore conclude that the influence of two effects is different for catechins than for other polyphenols in the set. Although EGCG shows the highest activity, its $E p_{a}$ is higher than $E p_{a}$ of Myr, implying that EGCG activity is caused more by chelate effect than the activity of Myr.

Acknowledgment. This work was supported by the Croatian Ministry of Science, Technology, Education and Sport, and Croatia-Serbia Bilateral Agreement 2016-2017.

\section{REFERENCES}

[1] A. Scalbert, I. T. Johnson, M. Saltmarsh, Am. J. Clin. Nutr. 2005, 81, $2015 \mathrm{~S}$.

[2] C. A. Rice-Evans, N. J. Miller, G. Paganga, Free Rad. Biol. Med. 1996, 20, 933.

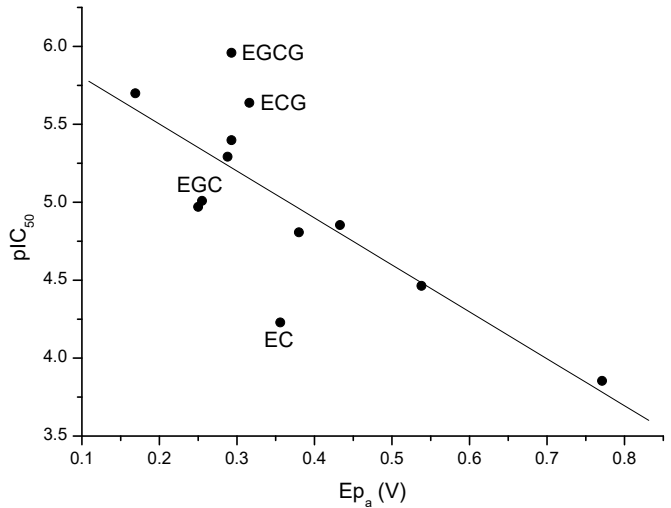

Figure 4. Correlation of experimental $E \mathrm{p}_{\mathrm{a}}$ to $\mathrm{pIC}_{50}$ values for 12 polyphenoles; $r=-0.770$, S.E. $=0.38$, S.E.cv $=0.43$. (Catechins are marked with the letter code.)

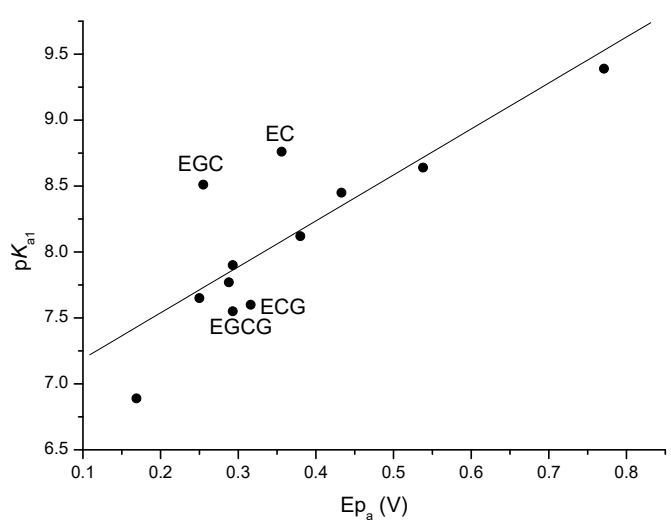

Figure 5. Correlation of experimental $E p_{\mathrm{a}}$ to $p K_{\mathrm{a} 1}$ values for 12 polyphenoles; $r=0.824$, S.E. $=0.37$, S.E.cv $=0.44$. (Catechins are marked with the letter code.)

[3] I. S. Young, J. V. Woodside, J. Clin. Pathol. 2001, 54, 176.

[4] B. Halliwell, Free Radic. Biol. Med. 2009, 46, 531.

[5] B. Badhani, N. Sharma, R. Kakkar, Roy. Soc. Chem. Adv. 2015, 5, 27540.

[6] H.-Y. Zhang, H.-G. Ji, New J. Chem. 2006, 30, 503.

[7] G. Litwinienko, K. U. Ingold, Acc. Chem Res. 2007, 40, 222.

[8] J. S. Wright, E. R. Johnson, G. A. DiLabio, J. Am. Chem. Soc. 2001, 123, 1173.

[9] N. R. Perron, J. L. Brumaghin, Cell. Biochem. Biophys. 2009, 53, 75.

[10] J. A. Imlay, S. Linn, Science 1988, 240, 1302.

[11] E. S. Henle, Z. Han, N. Tang, P. Rai, Y. Luo, S. Linn, J. Biol. Chem. 1999, 274, 962.

[12] A. C. Mello-Filho, R. Meneghini, Mutat. Res. 1991, 251, 109. 
[13] L. Macomber, C. Rensing, J. A. Imlay, J. Bacteriol. 2007, 189, 1616.

[14] C. Zhao, G. Dodin, C. Yuan, H. Chen, R. Zheng, Z. Jia, B.-T. Fan, Biochim. Biophys. Acta 2005, 1723, 114.

[15] N. R. Perron, J. N. Hodges, M. Jenkins, J. L. Brumaghim, Inorg. Chem. 2008, 47, 6153.

[16] G. Erdogan, R. Karadag, E. Dolen, Revs. Anal. Chem. 2005, 24, 247.

[17] L. B. Escudero, C. M. Fusari, J. C. Altamirano, A. B. Camargo, R. G. Wuilloud, J. Food Sci. 2014, 79, C1933.

[18] G. Le Nest, O. Caille, M. Woudstra, S. Rodche, B. Burlat, V. Belle, B. Guigliarelli, D. Lexa, Inorg. Chim. Acta 2004, 357, 2027.

[19] M. Andjelković, J. Van Camp, B. De Meulenaer, G. Depaemelaere, C. Socaciu, M. Verloo, R. Verhe, Food Chem. 2006, 98, 23.

[20] S. Teixeira, C. Siquet, C. Alves, I. Boal, M. P. Marques, F. Borges, J. L. F. C. Lima, S. Reis, Free Rad. Biol. Med. 2005, 39, 1099.

[21] R. C. Hider, Z. D. Liu, H. H. Khodr in Methods in Enzymology; Vol. 335 (Ed.: L. Packer) Academic Press, San Diego, 2001; pp 190-203.
[22] J. E. Brown, H. Khodr, R. C. Hider, C. A. Evans, Biochem. J. 1998, 330, 1173.

[23] N. R. Perron, C. R. García, J. R. Pinzón, M. N. Chaur, J. L. Brumaghim, J. Inorg. Biochem. 2011, 105, 745.

[24] G. Kothandan, C. G. Gadhe, T. Madhavan, C. H. Choi, S. J. Cho, Eur. J. Med. Chem. 2011, 46, 4078.

[25] J. Boccard, F. Bajot, A. DiPietro, S. Rudaz, A. Boumendjel, E. Nicolle, P. A. Carrupt, Eur. J. Pharm. Sci. 2009, 36, 254.

[26] A. Miličević, N. Raos, Arh. Hig. Rada Toksikol. 2016, $67,55$.

[27] E. Dičkancaité, A. Nemeikaité, A. Kalvelyté, N. Čénas, Biochem. Mol. Biol. Intern. 1988, 45, 923.

[28] M. Filipović, Z. Marković, J. Đorović, J. Dimitrić Marković, B. Lučić, D. Amić, C. R. Chemie 2015, 18, 492.

[29] D. Amić, D. Davidović-Amić, D. Bešlo, N. Trinajstić, Croat. Chem. Acta 2003, 76, 55.

[30] R. F. V. Souza, E. M. Sussuchi, W. F. Giovani, Synt. React. Inorg. Met.-Org. Chem. 2003, 33, 1125.

[31] B. Lučić, N. Trinajstić, J. Chem. Inf. Comput. Sci. 1999, 39, 121. 